\title{
Molecular identification of Coccidioides spp. in soil samples from Brazil
}

\author{
Regina CL de Macêdo ${ }^{1,2^{*}}$, Alexandre S Rosado ${ }^{2}$, Fabio F da Mota ${ }^{3}$, Maria AS Cavalcante ${ }^{4,5}$, Kelsen D Eulálio ${ }^{5}$, \\ Antônio D Filho ${ }^{5}$, Liline MS Martins ${ }^{4,5}$, Márcia S Lazéra ${ }^{1}$ and Bodo Wanke ${ }^{1}$
}

\begin{abstract}
Background: Since 1991 several outbreaks of acute coccidioidomycosis (CM) were diagnosed in the semi-arid Northeast of Brazil, mainly related to disturbance of armadillo burrows caused by hunters while digging them for the capture of these animals. This activity causes dust contaminated with arthroconidia of Coccidioides posadasii, which, once inhaled, cause the mycosis. We report on the identification of $C$. posadasii in soil samples related to outbreaks of CM.

Results: Twenty four soil samples had their DNA extracted and subsequently submitted to a semi-nested PCR technique using specific primers. While only $6(25 \%)$ soil samples were positive for C. posadasii by mice inoculation, all (100\%) were positive by the molecular tool.

Conclusion: This methodology represents a simple, sensitive and specific molecular technique to determine the environmental distribution of Coccidioides spp. in endemic areas, but cannot distinguish the species. Moreover, it may be useful to identify culture isolates. Key-words: 1. Coccidioidomycosis. 2. Coccidioides spp. 3. C. posadasii. 4. Semi-arid. 5. Semi-nested PCR
\end{abstract}

\section{Background}

Coccidioidomycosis is a systemic mycosis acquired by inhalation of infective arthroconidia from Coccidioides immitis or C. posadasii [1], which are pathogenic species of dimorphic fungi that live saprobiotically in soil from arid regions of the western hemisphere [2]. The largest known endemic area covers the southwestern United States and all of semi-arid northern Mexico $[3,4]$. Coccidioidomycosis also occurs in several semiarid areas of Central and South America [5,6]. The most recent endemic area was discovered in Brazil, where the first two autochthonous cases acquired the infection in semi-arid regions of the states of Bahia and Piaui in 1978 and 1979. Since then, several cases have been diagnosed in these states and also in the states of Ceará and Maranhão [7,8].

Coccidioides immitis and C. posadasii are the only species included in the genus Coccidioides. These two species are morphologically identical but genetically and

\footnotetext{
* Correspondence: regina.macedo@ipec.fiocruz.br

'Laboratório de Micologia do Instituto de Pesquisa Clínica Evandro Chagas, Fundação Oswaldo Cruz, Rio de Janeiro, Brasil

Full list of author information is available at the end of the article
}

epidemiologically distinct $[1,9]$ : C. immitis is geographically limited to California's San Joaquin valley, whereas C. posadasii is found in the remaining semi-arid areas in the southwest of the United States, Mexico, Central and South America.

Stewart \& Meyer in 1932 reported the first isolation of C. immitis from soil, proving that this substrate is the primary source for coccidioidomycosis. They studied soil samples collected from a disturbed site in the San Joaquin river valley (California, USA) that was the possible source of an acute coccidioidomycosis outbreak [10]. Another important contribution to environmental studies on Coccidioides spp. was reported by Emmons in 1942, which was able to isolate the fungus from soil samples and from wild rodents in a known endemic area [11]. The fungus has been isolated by animal inoculation of a soil suspension in sterile saline, a method still considered to be gold standard for detecting fungus in environmental samples. As this method detects the parasitic spherule form in animal tissues, it permits the precise identification of Coccidioides spp. Unfortunately it is also an expensive methodology with relatively low

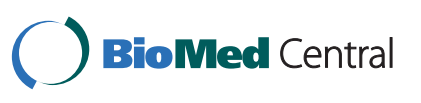


sensitivity, and the results take a long time to obtain, usually up to 45 days $[7,12,13]$.

The method of simply culturing soil samples on cycloheximide containing media slants is also very laborious, expensive, time consuming and of biological risk for the laboratory personnel. Comparing this method with that of animal inoculation, it is not able to demonstrate the parasitic form, necessary to ascertain the isolation of Coccidioides spp. [13].

In Brazil, the isolation of Coccidioides spp. from soil by animal inoculation has been used in some environmental investigations of small outbreaks of acute pulmonary coccidioidomycosis in armadillo hunters who are used to dig armadillo's burrows. Soil samples were collected inside and around armadillo's excavated burrows, ten to twenty samples, covering a small area of 4 to $6 \mathrm{~m}^{2}$. This method demonstrated the fungus in around $15 \%$ of the soil samples and it is important to emphasize that negative samples were often collected a few centimeters away from the positive ones. Thus, it is possible that viable elements of $C$. posadasii, with low metabolic activity and/or with low virulence, may be present in a soil sample but remain undetected by culture $[7,14]$.

In the county of Oeiras, Piauí state, C. posadasii was isolated from three (12.5\%) out of 24 soil samples collected in and around an excavated armadillo (Dasypus novemcinctus) burrow [7]. The same group of investigators obtained more environmental isolates of C. posadasii from soil samples related to excavation of armadillo (D. novemcinctus) and paca (Cuniculus paca) burrows in the county of Miguel Leão, Piauí [15-17].

Using multiplex PCR with two molecular markers, Greene et al (2000) demonstrated the presence of $C$. immitis in only four $(0.55 \%)$ out of 720 soil samples collected in endemic areas of coccidioidomycosis in California (USA) [12].

The molecular identification of Coccidioides spp. in environmental samples depends on several factors, especially the sampling site, storage conditions, processing techniques, DNA extraction methods, and adequate choice of the genetic target.

There is a growing need in the knowledge of the global geographical distribution of Coccidioides spp., their focal distribution in endemic areas and their genetic diversity in the environment. In fact the development of efficient molecular tool for the environmental identification of Coccidioides spp. is a continuous challenge in order to comprehend the ecology and biogeography of this important pathogen.

The present study aimed to detect Coccidioides spp. in soil samples, related to small outbreaks of CM, by culture and molecular methods.

\section{Methods}

The study was approved by the Institutional Ethics Committee of the Center for Biological Evaluation and Care of Research Animals at Fiocruz, no. P.0173-03 (COBEA at FIOCRUZ).

\section{Environmental soil sampling}

Twenty-four soil samples were collected from two different sites suspected to be contaminated by C. posadasii in the counties of Caridade do Piauí $\left(7^{\circ} 43^{\prime} 59^{\prime \prime} \mathrm{S}, 40^{\circ}\right.$ 59'23' W) and Elesbão Veloso (6 $12^{\circ} 07^{\prime \prime}$, 42 $\left.42^{\circ} 08^{\prime} 25^{\prime \prime} \mathrm{W}\right)$, situated $447 \mathrm{~km}$ and $156 \mathrm{~km}$, respectively, from Teresina, the capital of the state of Piauí, in the northeast region of Brazil, which includes a vast semi-arid area. Soil samples were collected, in both sites, in burrows that were dug by the hunters who presented acute respiratory CM 9 to 14 days after the risk activity. Ten soil samples were collected in Elesbão Veloso (EV1EV10) and 14 were collected in Caridade do Piauí (CP01, CP07, CP09 and CP12-CP22). The samples were placed into $100 \mathrm{~mL}$ sterile bags to be processed in Rio de Janeiro, at the Mycology Laboratory of IPEC/FIOCRUZ, according to both protocols: 1) animal inoculation in mice and 2) molecular detection. All soil samples were kept at room temperature (ranging from 20 to $28^{\circ} \mathrm{C}$ ) till the arrival at FIOCRUZ in Rio de Janeiro.

As negative soil controls, eight environmental samples were collected in the savanna of central Brazil: four in Goiânia (LL 2611, 19 261101, V 2611 e C 261101) and four in Brasília (DF21, DF22, DF23 e DF24).

\section{Animal inoculation}

The soil samples were processed and analyzed according to the classical technique described by Stewart \& Meyer (1932), modified as follows: samples were weighed, and $1 \mathrm{~g}$ was mixed in $50 \mathrm{~mL}$ of $0.9 \%$ sterile saline with chloramphenicol $(500 \mathrm{mg} / \mathrm{L})$. Each suspension was vortexed and allowed to settle for 30 minutes at room temperature $\left(25^{\circ} \mathrm{C}\right)$. The supernatant was aspirated, and 1 $\mathrm{mL}$ was inoculated intraperitoneally into four albino Swiss mice weighing 18-20 g. One control animal was used for each soil sample [10]. Animal necropsy was performed after four weeks of incubation or immediately after an animal death before the end of the incubation period. The animals were sacrificed in a $\mathrm{CO}_{2}$ chamber according to recommendations of COBEA. Liver and spleen samples were processed for a) direct mycological microscopy in wet mount preparations with $10 \% \mathrm{KOH}$; b) culture by inoculation onto Sabouraud 2\% glucose agar medium DIFCO ${ }^{\circledR}$ with and without cycloheximide; and c) preservation in 10\% formalin for histopathological study. Control animals were not inoculated, but 
were maintained in a separate cage and subsequently submitted to the same protocol as the inoculated animals. This method is considered the gold standard for the isolation and identification of culture isolates suspected of being C. immitis or C. posadasii.

\section{DNA extraction from soil}

The DNA was obtained using the Fast DNA ${ }^{\circledR} \operatorname{SPIN}^{\circledR}$ Kit for soil (Q-BIOgene, Carlsbad, CA, USA) following the manufacturer's instructions. Soil DNA was analyzed by electrophoresis in $0.8 \%(\mathrm{w} / \mathrm{v})$ agarose gels in TrisBorate-EDTA buffer as well as in a spectrophotometer at $260 \mathrm{~nm}$ absorbance (Beckman DU-600) to check its amount, purity and molecular size. Final DNA obtained from soil samples had large molecular length (>10 kb) and the humic acids contamination was not observed in electrophoresis gel. Therefore, DNA samples could be used as template to amplify $28 \mathrm{~S}$ rDNA by PCR. DNA extracts were amplified by Polymerase chain reaction (PCR) using $1 \mu \mathrm{l}$ of the extract (5 to $10 \mathrm{ng}$ of DNA g soil $^{-1}$ ) per $50 \mu$ of reaction.

\section{Characterization of soil-extracted DNA}

Soil-extracted DNA was amplified using the universal primers U1 and U2, which amplify a 260-bp product of a subunit of $28 \mathrm{~S}$ fungal rDNA, to demonstrate the absence of PCR inhibitors and the presence of fungi in the sample, as described previously [18]. A negative control without DNA was included in all amplifications.

\section{DNA extraction from clinical and environmental isolates of Coccidioides spp}

DNA of 21 clinical and environmental isolates of Coccidioides spp. was included in this study. From the Fungal Culture Collection at IOC/FIOCRUZ, six were identified as C. immitis (USA) and two as C. posadasii (Argentina); thirteen (nine clinical and four environmental) isolates identified as C. posadasii from Piauí/Brazil were preserved at the Laboratory of Mycology at IPEC/FIOCRUZ [19].

\section{DNA of other species of fungi and bacteria}

DNA of several species of fungi (41) and bacteria (3) were included in the study: Sporothrix schenckii (5); Paracoccidioides brasiliensis (5); Histoplasma capsulatum (2); Aspergillus niger (3); Aspergillus fumigatus (3); Aspergillus nidulans (3); Blastomyces dermatitidis (1); Microsporum canis (1); Trichophyton rubrum (1); Trichophyton mentagrophytes (1); Cryptococcus neoformans (6); C. gattii (10); Rhodococcus equi (1); Mycobacterium avium (1); and Paenibacillus sp. strain 9500615. The isolates were preserved at the Laboratory of Mycology at IPEC/FIOCRUZ or obtained from soil samples preserved at the Laboratório de Ecologia Microbiana Molecular of IMPPG/UFRJ.

\section{Design of specific primers for Coccidioides}

Initially, a BLASTn [20] search of GenBank revealed that the specific probe (5'-TCTGGCGGTTGGTT-3') for C. immitis proposed by Sandhu et al. (1995) presents $100 \%$ similarity with three C. immitis $28 \mathrm{~S}$ rDNA sequences deposited in the database [18]. However, this probe also presents $100 \%$ similarity with more than two hundred sequences of several other soil fungi and bacteria, leading the development of a new probe specific for Coccidioides. To obtain this new probe, all the $28 \mathrm{~S}$ rDNA sequences of Coccidioides spp. and all other fungi deposited at GenBank until June 22, 2010, were aligned using the CLUSTAL X software [21]. Probes were designed based on conserved sequences of Coccidioides spp., and BLASTn software was used to identify specific probes for Coccidioides [20]. A probe designated RFA12 (5'-TCCCCCATGCTCCGGGCC-3') presented 100\% sensitivity and specificity for all 22 sequences of Coccidioides (8 of C. immitis and 14 of C. posadasii) deposited at GenBank until June 2008 and was used together with an previously described probe P2 (5'CTCTGGCTTCACCCTATTC-3') [18] to amplify a fragment of Coccidioides $28 \mathrm{~S}$ rDNA of around $375 \mathrm{bp}$. It was also evaluated the efficiency of a semi-nested PCR system, by using the pair of primers RFA12 and RFA13 (5'-TAATCATTCGCTTTACCTCA-3') which amplify a fragment around $520 \mathrm{bp}$, in a step before the using of RFA12 and P2 primers.

\section{Standardization of PCR from soil samples}

To standardize a sensitive and specific molecular tool for detecting Coccidioides spp. in soil, the following steps were performed:

\section{PCR for cultured microorganisms}

The PCR reaction mixture consisted of $1 \mu$ of genomic DNA suspended in a mixture $5 \mu \mathrm{l} 10 \times$ PCR buffer $(10$ $\mathrm{mM}$ Tris (pH 9.0), $500 \mathrm{mM} \mathrm{KCl}$ ), $2.5 \mu \mathrm{l}$ of $10 \mathrm{mM}$ dNTPs, $5 \mu \mathrm{l} 25 \mathrm{mM} \mathrm{MgCl} 2,1 \mu \mathrm{l}$ of each primer (RFA12/P2; $10 \mathrm{pmol} / \mu \mathrm{l}), 1.25 \mu \mathrm{l}$ of $5 \mathrm{U}$ AmpliTaq DNA polymerase, and $33.25 \mu \mathrm{l}$ of MilliQ water. PCR amplification was performed with the primers (RFA12/P2) in a DNA thermal cycler. The temperature profile included an initial denaturation step at $94^{\circ} \mathrm{C}$ for $5 \mathrm{~min} ; 30$ cycles of $94^{\circ} \mathrm{C}$ for $30 \mathrm{~s}, 55^{\circ} \mathrm{C}$ for $1 \mathrm{~min} 30 \mathrm{~s}$, and $72^{\circ} \mathrm{C}$ for 1 min; followed by a single terminal extension at $72^{\circ} \mathrm{C}$ for $3 \mathrm{~min}$. As negative control, water instead of template was performed at all PCR reactions.

\section{Semi-nested PCR for cultured microorganisms}

The reaction mixture of the the primary round PCR (RFA12/RFA13) consisted of $1 \mu \mathrm{l}$ of DNA extract in a total volume of $50 \mu \mathrm{l}$ with $5 \mu \mathrm{l} 10 \times$ PCR buffer $(10$ Mm Tris (pH 9.0), 500 mM KCl), $2.5 \mu l 10$ mM dNTPs, 
$5 \mu \mathrm{l} 25 \mathrm{mM} \mathrm{MgCl} 2,1 \mu \mathrm{l}$ of each primer $(10 \mathrm{pmol} / \mu \mathrm{l})$, $1.25 \mu \mathrm{l}$ of $5 \mathrm{U}$ AmpliTaq DNA polymerase, and $33.25 \mu \mathrm{l}$ of MilliQ water. The reaction cycles included an initial denaturation step at $94^{\circ} \mathrm{C}$ for $5 \mathrm{~min} ; 20$ cycles of $94^{\circ} \mathrm{C}$ for $30 \mathrm{~s}, 55^{\circ} \mathrm{C}$ for $1 \mathrm{~min} 30 \mathrm{~s}$, and $72^{\circ} \mathrm{C}$ for $1 \mathrm{~min}$; followed by a single terminal extension at $72^{\circ} \mathrm{C}$ for $3 \mathrm{~min}$. Reaction mixtures of $2^{\circ} \mathrm{PCR}$ round (RFA12/P2) was identical, except by primers and $1 \mu \mathrm{l}$ of the first reaction was added as template to the second reaction. Reaction mixtures with second primer set (RFA12/P2) were thermally cycled once at $94^{\circ} \mathrm{C}$ for $5 \mathrm{~min}, 30$ times at $94^{\circ} \mathrm{C}$ for $30 \mathrm{~s}, 55^{\circ} \mathrm{C}$ for $1 \mathrm{~min} 30 \mathrm{~s}$, and $72^{\circ} \mathrm{C}$ for $1 \mathrm{~min}$, followed by a single terminal extension at $72^{\circ} \mathrm{C}$ for $3 \mathrm{~min}$.

\section{PCR of soil}

The reaction mixture of the primary PCR consisted of 1 $\mu \mathrm{l}$ of DNA extract in a total volume of $50 \mu \mathrm{l}$ with $5 \mu \mathrm{l}$ $10 \times$ PCR buffer (10 mM Tris (pH 9.0), $500 \mathrm{mM} \mathrm{KCl})$, $1 \mu \mathrm{l} 10 \mathrm{mM}$ dNTPs, $2.5 \mu \mathrm{l} 50 \mathrm{mM} \mathrm{MgCl}_{2}, 1 \mu \mathrm{l}$ of each primer (RFA12/P2; $10 \mathrm{pmol} / \mu \mathrm{l}), 0.5 \mu \mathrm{l} 10 \mathrm{mg} / \mu \mathrm{l} \mathrm{BSA}$, $0.5 \mu \mathrm{l} 100 \%$ formamide, $0.5 \mu \mathrm{l}$ of $5 \mathrm{U}$ AmpliTaq DNA polymerase and $37 \mu \mathrm{l}$ MilliQ water. The reaction cycles included an initial denaturation step at $94^{\circ} \mathrm{C}$ for $5 \mathrm{~min}$, 35 cycles at $94^{\circ} \mathrm{C}$ for $45 \mathrm{~s}, 55^{\circ} \mathrm{C}$ for $1 \mathrm{~min} 30 \mathrm{~s}$, and $72^{\circ}$ $\mathrm{C}$ for $2 \mathrm{~min}$, followed by a single terminal extension at $72^{\circ} \mathrm{C}$ for $3 \mathrm{~min}$.

\section{Semi-nested PCR from soil}

The reaction mixture of the primary round PCR (RFA12/RFA13) consisted of $1 \mu$ l of DNA extract in a total volume of $50 \mu \mathrm{l}$ with $5 \mu \mathrm{l} 10 \times \mathrm{PCR}$ buffer $(10$ $\mathrm{mM}$ Tris (pH 9.0), $500 \mathrm{mM} \mathrm{KCl}$ ), $1 \mu \mathrm{l} 10 \mathrm{mM}$ dNTPs, $2.5 \mu \mathrm{l} 50 \mathrm{mM} \mathrm{MgCl}, 1 \mu \mathrm{l}$ of each primer $(10 \mathrm{pmol} / \mu \mathrm{l})$, $0.5 \mu \mathrm{l} 10 \mathrm{mg} / \mu \mathrm{l} \mathrm{BSA}, 0.5 \mu \mathrm{l} 100 \%$ formamide, $0.5 \mu \mathrm{l}$ of 5 U AmpliTaq DNA polymerase and $37 \mu \mathrm{l}$ MilliQ. The reaction cycles included an initial denaturation step at $94^{\circ} \mathrm{C}$ for $5 \mathrm{~min}, 25$ cycles of $94^{\circ} \mathrm{C}$ for $45 \mathrm{~s}, 55^{\circ} \mathrm{C}$ for 1 min $30 \mathrm{~s}$, and $72^{\circ} \mathrm{C}$ for $2 \mathrm{~min}$, and a single terminal extension at $72^{\circ} \mathrm{C}$ for $3 \mathrm{~min}$. Reaction mixtures of $2^{\circ}$ PCR round was identical, except by primers and that 1 $\mu \mathrm{l}$ of the first reaction was added as template to the second reaction. Reaction mixtures with second primer set (RFA12/P2) were thermally cycled once at $94^{\circ} \mathrm{C}$ for 5 min, 35 times at $94^{\circ} \mathrm{C}$ for $45 \mathrm{~s}, 55^{\circ} \mathrm{C}$ for $1 \mathrm{~min} 30 \mathrm{~s}$, and $72^{\circ} \mathrm{C}$ for $2 \mathrm{~min}$, and a single terminal extension at $72^{\circ} \mathrm{C}$ for $3 \mathrm{~min}$. A negative control without DNA was included in all amplifications.

\section{Evaluation of sensitivity of the semi-nested PCR}

The sensitivity of the semi-nested PCR method was determined with primers specific for C. immitis (RFA12/ RFA13 and RFA12/P2) using DNA of a C. posadasii isolate, either pure (without dilution) or diluted by $10^{-2}$, $10^{-3}$ and $10^{-4}$ in water free of DNAse and RNAse. Next,
$0.5 \mu \mathrm{l}$ of negative soil DNA (soil from an area without coccidioidomycosis) was added to $0.5 \mu$ l of each pure and diluted DNA sample in triplicate. All products obtained by direct PCR and semi-nested PCR were subjected to electrophoresis in a $1.2 \%$ agarose gel with $1 \times$ TBE buffer (89 mM Tris-borate, $2.5 \mathrm{mM}$ EDTA [pH 8.0]) for $2 \mathrm{~h}$, and a $1 \mathrm{~Kb}$ DNA Ladder (Promega) served as molecular marker. The gel was then stained for 15 min with $0.5 \mu \mathrm{g} \mathrm{ml}^{-1}$ ethidium bromide and observed under short-wavelength ultraviolet light. The image was captured by an IMAGO system.

\section{Results}

\section{Animal inoculation}

C. posadasii was isolated by intraperitoneal inoculation into mice, from 6 (25\%) out of the 24 soil samples studied: 3 out of 10 (30\%) from Elesbão Veloso and 3 out of 14 (21.4\%) from Caridade do Piauí.

\section{Molecular methods}

The DNA obtained from each soil sample was of excellent quality, with its molecular weight concentrated above $1.5 \mathrm{~kb}$

\section{PCR and semi-nested PCR applied to DNA of cultured of Coccidioides spp. and controls}

Direct PCR with primers specific for Coccidioides spp. (RFA12/P2) was able to identify 19 out of the 21 Coccidioides spp. isolates tested, which presented the specific 375-bp band. However, semi-nested PCR using the same primers, RFA12/RFA13 and RFA12/P2, was able to identify all the 21 isolates tested (Figures 1 and 2). The same direct and semi-nested PCR methodologies presented negative results when applied to DNA of all species of other different pathogenic fungi and bacteria. These results demonstrate the high specificity of the primers developed in this study and highlight the increased sensitivity, expected in semi-nested PCR reactions from environmental samples.

\section{PCR and semi-nested PCR applied to soil DNA samples}

The DNA obtained from the soil samples was submitted to direct PCR and semi-nested PCR using the same primer system. Only 8 out of 24 (33.3\%) soil samples presented the specific 375-bp band by direct PCR: 2/10 from Elesbão Veloso and 6/14 from Caridade do Piauí (Data not shown). However, using semi-nested PCR with the primers RFA12/RFA13 and RFA12/P2, all the soil samples presented the specific 375-bp band indicative of Coccidioides spp. (Figure 3). By the same molecular method, the DNA obtained from the soil of central Brazil presented 100\% negative results. The results comparing both classical and molecular methods to detect Coccidioides spp. in soil samples are summarized in Table 1. 


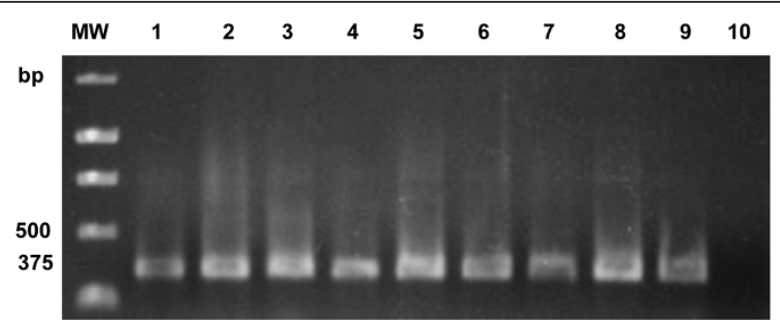

Figure 1 1.2\% agarose gel showing results of semi-nested PCR with primers RFA12/RFA13 and RFA12/P2 specifics for Coccidioides spp., lines 1-4 DNA isolated of C. immitis (US), lines 5-9 DNA isolated of C. posadasii (Piauí/Brazil), and line 10 negative control (DNA C. neoformans). MW = $1 \mathrm{~Kb}$ DNA Ladder (Promega).

Evaluation of the sensitivity of the semi-nested PCR for detecting specific sequences of Coccidioides spp Semi-nested PCR with primers specific for Coccidioides spp. (RFA12/RFA13 and RFA12/P2) when applied to DNA of C. posadasii in serial dilutions was sufficiently sensitive to detect specific $C$. immitis $28 \mathrm{~S}$ rDNA, generating a product of 375 -bp, as visualized in a $1.2 \%$ agarose gel (Figure 4).

\section{Discussion}

Inoculation into mice has long been the classical method for isolating and identifying pathogenic fungi present in environmental samples such as soil. Many studies have been performed over several decades, mainly by intraperitoneal inoculation into albino, nonisogenic and non-immunocompromised mice, thereby producing knowledge on the geographic distribution, natural habitats and environmental microfoci of pathogenic fungi, especially Histoplasma and Coccidioides spp.

Due to its nature, the animal model works as a biological filter, selecting species or lineages thermo tolerant to $35-37^{\circ} \mathrm{C}$ with metabolic and genetic properties that permit their survival and multiplication in mammalian tissues. Usually, when suspected soil material is inoculated intraperitoneally, the saprobic microbiota composed of bacteria and fungi are blocked and eliminated by the immune system of the inoculated mice. In the presence of fungal agents of systemic mycoses, they may multiply and disseminate to regional lymph nodes and other organs like the lungs, liver, spleen, kidneys, skin and/or central nervous system. Spleen and liver were the organs that allowed the highest positivity for isolating Coccidioides spp. of the inoculated mice [10].

Coccidioides spp. isolates have been obtained from soil samples of known endemic areas. Usually, the positivity is very low when the samples are collected randomly, even in endemic areas; however, when sampling is directed to a specific suspected site related to cases of acute pulmonary coccidioidomycosis with a consistent epidemiological history of dust inhalation, the probability of obtaining positive samples increases significantly. In fact, such sites may harbor microfoci of Coccidioides spp. where they find suitable ecological conditions to multiply and reach high spore concentrations in restricted areas. These quantitative aspects have been demonstrated for Cryptococcus neoformans and $C$. gattii through plating onto selective Niger Seed agar (NSA) medium, which allows the concentration of viable fungal propagules to be estimated [22]. Nevertheless, this plating method is not used to detect the agents of coccidioidomycosis due to its high biological risk and because other fast-growing saprobic fungi may lead to misidentification. Thus, there are no adequate tools for estimating the concentration of Coccidioides spp. elements in various substrata, natural habitats or environmental sources related to outbreaks of coccidioidomycosis, where high concentrations of the fungus may exist.

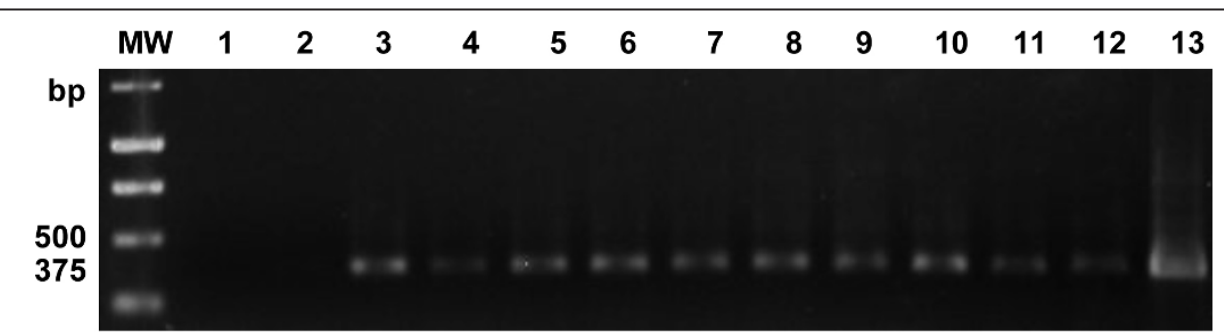

Figure 2 1.2\% agarose gel showing results of semi-nested PCR with primers RFA12/RFA13 and RFA12/P2 specifics for Coccidioides spp. lines 1-2 DNAs Rhodococcus equi 33701 e Mycobacterium avium 13956, lines 3-4 DNA isolated of C. immitis (US), lines 5-6 DNA isolated of C. posadasii (Argentina) and lines 7-13 DNA isolated of C. posadasii (Piauí/Brazil) MW = $1 \mathrm{~Kb}$ DNA Ladder (Promega). 


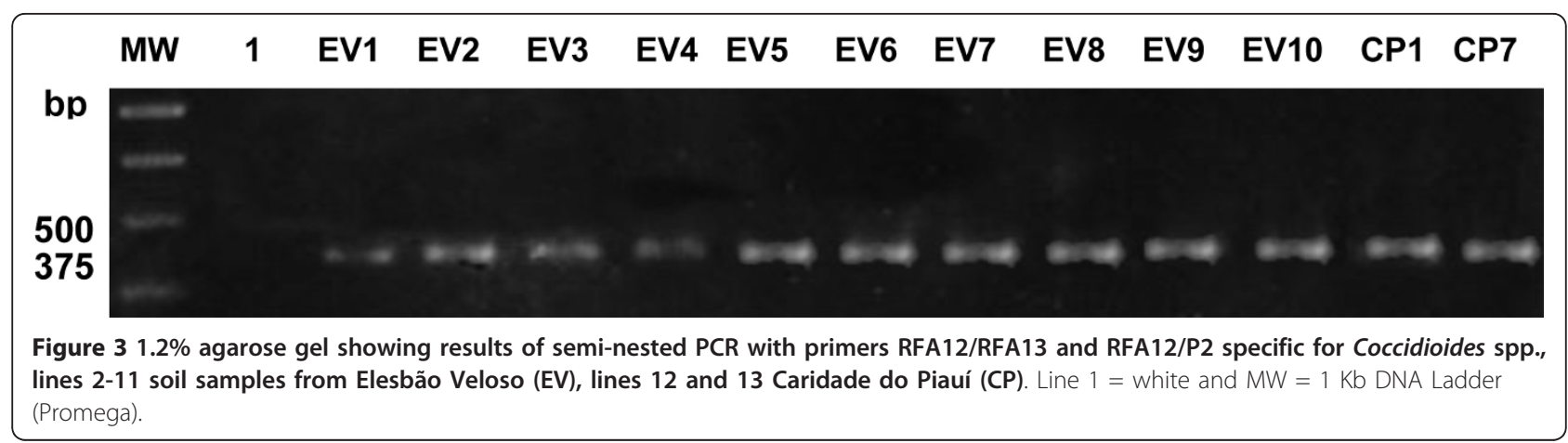

The low frequency of C. immitis isolation from soil samples may be due to seasonal variations or a nonhomogeneous distribution in the soil. A study conducted in the US investigated environmental samples collected over eight years in the same endemic area detected the presence of $C$. immitis, ranging from 0 43\% [14]. Few environmental isolates of C. immitis and C. posadasii from endemic areas of Mexico and the United States are available for scientific purposes. Recent studies on the phylogeny and molecular

Table 1 Detection of C. posadasii in soil samples by classical and molecular methods in Piauí, Brazil.

\begin{tabular}{|c|c|c|c|}
\hline Soil sample & Animal inoculation & Direct PCR & Semi-nested PCR \\
\hline$\overline{\text { EV1 }}$ & - & - & + \\
\hline EV2 & - & + & + \\
\hline EV3 & - & - & + \\
\hline EV4 & - & + & + \\
\hline EV5 & - & - & + \\
\hline EV6 & + & - & + \\
\hline EV7 & - & - & + \\
\hline EV8 & + & - & + \\
\hline EV9 & - & - & + \\
\hline EV 10 & + & - & + \\
\hline CP1 & - & - & + \\
\hline CP7 & - & - & + \\
\hline CP9 & - & - & + \\
\hline CP12 & - & - & + \\
\hline CP13 & - & - & + \\
\hline CP14 & - & - & + \\
\hline CP15 & - & - & + \\
\hline CP16 & - & + & + \\
\hline CP17 & + & + & + \\
\hline CP18 & + & + & + \\
\hline CP19 & + & + & + \\
\hline CP20 & - & + & + \\
\hline CP21 & - & + & + \\
\hline $\mathrm{CP} 22$ & - & - & + \\
\hline
\end{tabular}

$\mathrm{EV}=$ Elesbão Veloso, $\mathrm{CP}=$ Caridade do Piauí,

$(-)=$ Negative and $(+)=$ Positive epidemiology of Coccidioides spp. were based mainly on clinical isolates from different geographical regions $[1,9]$. Therefore, environmental isolates of C. posadasii from semi-arid northeastern Brazil are of interest for these studies.

Regarding the environmental samples collected in and around two excavated armadillo ( $D$. novemcinctus) burrows in Elesbão Veloso and Caridade do Piauí, we obtained positivity rates of $30 \%$ and $21.4 \%$, respectively, using the mouse inoculation method. These rates seem very satisfactory when compared to literature data Greene et al. 2000 [12]. The low number of soil samples collected in a specific contaminated habitat excavated during armadillo hunting may have contributed to these results. Moreover, it should be taken into consideration that only a small amount ( $1 \mathrm{~g})$ from each soil sample was examined after suspending it in $50 \mathrm{~mL}$ of saline, from which only $0.5 \mathrm{~mL}$ was inoculated into each mouse. Thus, it is possible that viable propagules of Coccidioides spp. present in the sample were not inoculated, producing a false negative result. Beyond the quantitative aspect, the animal model is incapable of detecting lineages unable to grow at $37^{\circ} \mathrm{C}$ or present in numbers too low to invade and grow in mammalian tissues. On the other hand, propagules with low metabolic activity can remain in latency in soil. In fact, most aspects of the population structure of Coccidioides spp. in the environment remain unknown.

Curiously, during the investigation of the samples from Caridade do Piauí, the same method of animal inoculation permitted the simultaneous isolation of C. posadasii and Cryptococcus neoformans from one soil sample, while C. neoformans was isolated from another soil sample that was negative for C. posadasii. These findings demonstrate the complexity of the fungal microbiota in environmental habitats, such as in this case of $D$. novemcinctus. These habitats are not exclusive to armadillos, but they are shared with wild rodents, snakes, scorpions, birds and many insects. In the surroundings of this armadillo burrow, it was observed a resting site of Zenaida auriculata, a New World tropical dove endemic to South America, 


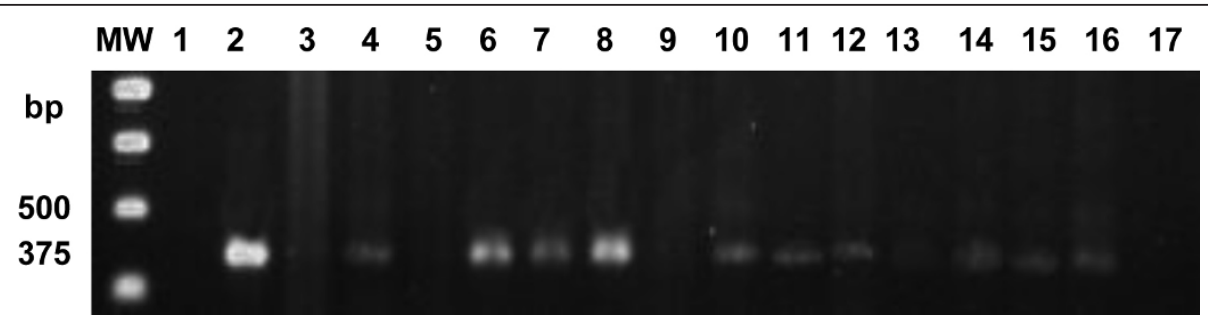

Figure 4 1.2\% agarose gel showing results of semi-nested PCR with primers RFA12/RFA13 and RFA12/P2 specific for Coccidioides spp., lines 1, 5, 9, 13 and 17 = white, lines 2-4 DNA C. posadasii (pure), lines 6-8 DNA C. posadasii (diluted at 10-2), lines 10-12 DNA C. posadasii (diluted a $10^{-3}$ ), lines 14-16 DNA C. posadasii (diluted $10^{-4}$ ). MW $=1 \mathrm{~Kb}$ DNA Ladder (Promega).

that appear periodically in this region. It is possible that Coccidioides spp., Cryptococcus neoformans and C. gattii, interacting together and/or with other living elements of the soil microbiota, as well as with several other hosts, may generate adaptations and select lineages of these pathogenic fungi. The demonstration of naturally acquired coccidioidomycosis in $D$. novemcinctus armadillos captured in Piauí reinforces the complexity of this subject [23]. Nevertheless, there have been no investigations of naturally acquired coccidioidomycosis in other species of armadillos, or in other animals such as rodents, foxes, goats, horses, donkeys, cattle and other mammals.

Molecular biological techniques have been used to identify pathogenic fungi. Sandhu et al. (1995) analyzed 116 cultures of several human pathogenic fungi using the universal primers U1 and U2 to amplify the conserved 28S rDNA region of fungi, which was then hybridized with probes specific for each fungal species [18]. Sixteen clinical isolates of $C$. immitis tested by this method demonstrated $100 \%$ positivity in identifying this species.

Another approach used for the identification of isolates of $C$. immitis is direct PCR using primers with nucleotide sequences based on the gene $c s a$, which is a $19-\mathrm{kDa}$ specific $C$. immitis antigen secreted in the growth phase of fungal cultures that generates a product of about $519 \mathrm{bp}$ [24]. In another study, Bezerra et al. (2006) obtained $100 \%$ positivity analyzing the DNA of 19 cultures of $C$. immitis: twelve clinical isolates from the state of Piauí and seven isolates preserved for 50-75 years in the culture collection of the Department of Mycology from the Instituto Oswaldo Cruz at FIOCRUZ in Rio de Janeiro [19].

Regarding the development of molecular methods for the detection of Coccidioides spp. directly in soil samples, obtaining an adequate DNA preparation represented a large challenge. Using mechanical agitation followed by direct cellular enzymatic lysis, we obtained DNA samples with a molecular weight concentrated above $1.5 \mathrm{~kb}$, which were suitable for the amplification reactions by PCR. It should be mentioned that only recently adequate equipment and a Fast DNA SPIN kit for soil (QBIOgene, Carlsbad, CA, USA) allowed the attainment of this suitable DNA from soil samples.

In the present study, the primers designed to detect Coccidioides spp. $28 \mathrm{~S}$ rDNA in soil took into consideration the low number of copies of the target DNA present in soil. This permitted the detection of Coccidioides spp. $28 \mathrm{~S}$ rDNA in six isolates from the USA and two from Argentina, as well as in thirteen Brazilian isolates. The molecular detection of any of the Coccidioides species in soil or in clinical specimens is of equal importance.

Optimization of direct PCR with specific primers to detect $C$. immitis was first performed with DNA extracted from 21 lineages of Coccidioides spp. (eight from the Fungal Culture Collection at IOC/FIOCRUZ, and nine clinical and four environmental isolates from the state of Piauí preserved at the Laboratory of Mycology of IPEC/FIOCRUZ). In this way, we detected a $28 \mathrm{~S}$ rDNA fragment with a product of nearly 375 bp in 19 out of the 21 isolates tested. However, applying a seminested PCR system to these DNA samples with a new pair of primers specific for Coccidioides spp., we detected bands of sizes compatible with the expected fragment in the DNA of all cultures tested. As a control, the DNA of 41 lineages of other human pathogenic fungi (S. schenckii, P. brasiliensis, H. capsulatum, A. niger, A. fumigatus, A. nidulans, B. dermatitidis, $M$. canis, T. rubrum, T. mentagrophytes, C. neoformans and C. gattii) were submitted to the same protocol, and all results were negative. The results were also negative when the protocol was applied to DNA from bacteria.

Our results indicate the high specificity of PCR with these primers and highlight the increased sensitivity, expected in nested PCR reactions using DNA obtained from soil samples. The next step was to optimize direct PCR with specific primers for detecting Coccidioides spp. in the DNA extracted from our 24 soil samples. The direct PCR method revealed the expected fragment only in 8 (33.3\%) soil samples, but when the semi-nested system was used, all the soil samples were positive, thus 
confirming to be a very sensitive method for detecting Coccidioides spp. $28 \mathrm{~S}$ rDNA. It is important to note that all of the positive soil samples were collected in and around armadillo burrows strongly suspected to be heavily contaminated because their disturbance caused acute cases of human and canine coccidioidomycosis. It is possible that these restricted sites harbor high concentrations of viable arthroconidia of $C$. immitis, which are easily detected by animal inoculation, as well as dormant or dead fungal elements with DNA partially preserved, which can only be detected by molecular tools. To evaluate these factors, it should be of interest to analyze soil samples collected in concentric circles from the center of the focus.

As controls for the PCR protocols applied to our soil samples from Piauí, we analyzed DNA extracted from soil samples collected in non-endemic areas of the cities of Goiânia (capital of the state of Goiás) and Brasília (Capital of Brazil), and none presented the 375-bp band, reinforcing our results. Thus, we believe it is important to note that the primer system RFA12 + P2 was able to identify both C. immitis and C. posadasii.

The molecular detection of Coccidioides spp. in suspected soil or in clinical specimens has obvious importance for epidemiological studies and laboratory diagnosis of coccidioidomycosis. Furthermore, molecular procedures such as PCR present substantial advantages, as they reduce the biological risk inherent in the classical techniques and reduce the time necessary to identify a suspected environmental focus or diagnose a clinical case to a few hours. On the other hand, this $28 \mathrm{~S}$ rDNA marker is not able to distinguish C. immitis from C. posadasii in positive soil samples. However, other markers can be used to detect these specific species. Umeyama et al. (2006) describe speciesspecific primers for C. immitis based on the ITS1 and ITS4 region, and they were able to differentiate isolates of C. immitis and C. posadasii [25].

The methodology described in the present study was found to be a sensitive and specific tool for detecting Coccidioides spp. in soil. We believe that the RFA12 + P2 primer system will be useful for epidemiological investigations of clinical cases as well as for environmental studies to identify hazardous sites in Brazil and elsewhere.

\section{Conclusions}

This study introduced a simple, sensitive and specific molecular technique to determine the environmental distribution of Coccidioides spp. in endemic areas, but cannot distinguish the species.

\section{Abbreviations}

COBEA at FIOCRUZ: Institutional Ethics Committee of the Center for Biological Evaluation and Care of Research Animals at Fiocruz; CM:
Coccidioidomycosis; EV: Elesbão Veloso; CP: Caridade do Piauí; IPEC: Instituto de Pesquisa Clínica Evandro Chagas; DF: Distrito Federal; IOC: Instituto Oswaldo Cruz; FIOCRUZ: Fundação Oswaldo Cruz

\section{Acknowledgements}

This study received financial support from the Foundation for Research Support of the State of Rio de Janeiro (FAPERJ) and Brazilian National Council for Scientific and Technological Development (CNPq) number 311.737/2006-4.

\section{Author details}

'Laboratório de Micologia do Instituto de Pesquisa Clínica Evandro Chagas, Fundação Oswaldo Cruz, Rio de Janeiro, Brasil. '2Laboratório de Ecologia Microbiana Molecular do Instituto de Microbiologia Paulo de Góes, Universidade Federal do Rio de Janeiro, Brasil. ${ }^{3}$ Laboratório de Biologia Computacional e Sistemas, Instituto Oswaldo Cruz, Fundação Oswaldo Cruz, Brasil. ${ }^{4}$ Universidade Estadual do Piauí, Teresina, Piauí, Brasil. ${ }^{5}$ Universidade Federal do Piauí, Teresina, Piauí, Brasil.

\section{Authors' contributions}

RCLM: Study design, primers design, fieldwork and data collection, laboratory tests, data analysis, manuscript writing; ASR: Study design, primers design, laboratory tests, data analysis, manuscript writing; FFM: Primers design, laboratory test, data analysis, manuscript writing; MASC: Fieldwork, data collection and analysis, manuscript writing; KDE: Fieldwork and data collection; ADF: Fieldwork and data collection; LMSM: Diagnostic laboratorial tests; MSL: Data interpretation and analysis, manuscript writing; BW: Coordination, study design, fieldwork and data collection, data analysis, manuscript writing. All authors read an approved the final draft.

\section{Authors' information}

RCLM: regina.macedo@ipec.fiocruz.br

ASR: asrosado@globo.com

FFM: fabio@ioc.fiocruz.br

MASC: normacely@uol.com.br

KDE: kelsendeulalio@yahoo.com.br

ADF: mdedeus@uol.com.br

LMSM: liline-martins@uol.com.br

MSL: marcia.lazera@ipec.fiocruz.br

BW: bodo.wanke@ipec.fiocruz.br

Received: 29 October 2010 Accepted: 16 May 2011

Published: 16 May 2011

\section{References}

1. Fisher MC, Koenig GL, White TJ, Taylor JW: Molecular and phenotypic description of Coccidioides posadasii sp. nov., previously recognized as the non-California population of Coccidioides immitis. Mycologia 2002, 94(1):73-84.

2. Pappagianis D: Epidemiology of coccidioidomycosis. In Current topics of medical mycology. Volume 2. Edited by: McGinnis MR. Springer-Verlag, New York; 1988:199-238.

3. Ajello L: Coccidioidomycosis and histoplasmosis: a review of its epidemiology and geographical distribution. Mycopathologia 1971, 45:221-230.

4. Hector RF, Laniado-Laborin R: Coccidioidomycosis -A fungal disease of the Americas. PloS Med 2005, 2(1):15-18.

5. Mayorga RP, Espinoza H: Coccidioidomycosis in México and Center America. Mycopath Mycol Appl 1970, 13-23.

6. Campins $\mathrm{H}$ : Coccidioidomycosis in South America. A review of its epidemiology and geographic distribution. Mycopath Mycol Appl 1970, 40:25-34.

7. Wanke B, Lazera ML, Monteiro PCF, Lima FC, Leal MJS, Ferreira Filho PL, Kaufman L, Pinner RW, Ajello L: Investigation of an outbreak of endemic coccidioidomycosis in Brazil's Northeastern State of Piauí with a review of the occurrence and distribution of Coccidioides immitis in three other Brazilian states. Mycopathologia 1999, 148:57-67.

8. Cordeiro RA, Brilhante RS, Rocha MF, Bandeira SP, Fechine MA, Camargo ZP Sidrim JJ: Twelve years of coccidioidomycosis in Ceará State, Northeast Brazil: epidemiologic and diagnostic aspects. Diagn Microbiol Infect Dis 2010, 66(1):65-72. 
9. Fisher MC, Koenig GL, White TJ, San-Blas G, Negroni R, Alvarez IG, Wanke B, Taylor JW: Biogeographic range expansion into South America by Coccidioides immitis mirrors New World patterns of human migration. Proc Natl Acad Sci USA 2001, 98(8):4558-4562.

10. Stewart RA, Meyer KF: Isolation of Coccidioides immitis (Stiles) from the soil. Proc Soc Exp Biol Med 1932, 29:937-938.

11. Emmons CW: Isolation of Coccidioides from soil and rodents. Pub Health Rep 1942, 57:109-111.

12. Greene DR, Koenig G, Fisher MC, Taylor JW: Soil isolation and molecular identification of Coccidioides immitis. Mycologia 2000, 92:406-410.

13. Cordeiro RA: Phenotypic characterization and ecological features of Coccidioides spp. from Northeast Brazil. Med Mycol 2006, 44:1-9.

14. Elconin AF, Egeberg RO, Egberg MC: Significance of soil salinity on the ecology of Coccidioides immitis. J Bacteriol 1964, 87(3):500-503.

15. Wanke B: Coccidioidomicose. Rev Soc Bras Med Trop 1994, 27(Supl 4):375-378.

16. Wanke B, Lazera MS, Monteiro PCF, Correia Lima F, Leal MJ, Ferreira Filho PL, Bezerra C: Coccidioidomicose no Estado do Piauí. Anais do I Congresso Bras de Micologia. Porto Alegre 1995.

17. Wanke B, Eulálio KD, Salmito MA, Cruz JRM, Lazera MS: Coccidioidomycosis among armadillo hunters in northeastern Brazil: a new outbreak in the state of Piaui. Annals of $4^{\circ}$ ISHAM World Congress, Buenos Aires 2000.

18. Sandhu GS, Kline BC, Stockman L, Roberts GD: Molecular Probes for Diagnosis of Fungal Infections. Journal of Clinical Microbiology 1995, 33(11):2913-2919.

19. Bezerra CFC, Lima RF, Lazera MS, Wanke B, Borba CM: Viability and molecular authentication of Coccidioides immitis strains from Culture Colletion of the Instituto Oswaldo Cruz, Rio de Janeiro, Brazil. Revista da Sociedade Brasileira de Medicina Tropical 2006, 39(3):241-244.

20. McGinnis S, Madden TL: BLAST: at the core of a powerful and diverse set of sequence analysis tools. Nucleic Acids Res 2004, 32:W20-W25.

21. Jeanmougin F, Thompson JD, Gouy M, Higgins DG, Gibson TJ: Multiple sequence alignment with Clustal X. Trends Biochem Sci 1998, 23:403-405.

22. Lazera MS, Pires FDA, Camillo-Coura L, Nishikawa MM, Bezerra CCF, Trilles L, Wanke B: Natural habitat of Cryptococcus neoformans var. neoformans in decaying wood forming hollows in living trees. J Med Veter Mycol 1996, 34:127-131.

23. Eulálio KD, Macêdo RL, Cavalcanti MAS, Martins LMS, Lazera MS, Wanke B: Coccidioides immitis isolated from armadillos (Dasypus novemcinctus) in the state of Piauí, northeast Brazil. Mycopathologia 2000, 149:57-61.

24. Pan S, Sigler L, Cole GT: Evidence for a phylogenetic connection between Coccidioides immitis and Uncinocarpus reesi (Onygenaceae). Mycrobiology 1994, 104:1481-1494.

25. Umeyama T, Sano A, Kamei K, Niimi M, Nishimura K, Uehara Y: Novel Approach to Designing Primers for Identification and distinction of the Human Pathogenic Fungi Coccidioides immitis and Coccidioides posadasii by PCR Amplification. Journal of Clinical Microbiology 2006, 44(5):1859-1862.

doi:10.1186/1471-2180-11-108

Cite this article as: de Macêdo et al:: Molecular identification of Coccidioides spp. in soil samples from Brazil. BMC Microbiology 2011 11:108.

\section{Submit your next manuscript to BioMed Central and take full advantage of:}

- Convenient online submission

- Thorough peer review

- No space constraints or color figure charges

- Immediate publication on acceptance

- Inclusion in PubMed, CAS, Scopus and Google Scholar

- Research which is freely available for redistribution 